\title{
Biological Activities of Toxin Produced by Tomato Canker Bacterium, Clavibacter michiganensis subsp. michiganensis, against Tomato Plant and Its Callus Cells
}

\author{
Bernardo Ueno*, Tohru TeraokA*, Daijiro Hosokawa* and Minoru Watanabe*
}

\begin{abstract}
Clavibacter michiganensis subsp. michiganensis, causal agent of bacterial canker of tomato, produces phytotoxic glycopeptide which causes wilting on tomato cuttings. In order to select toxin-tolerant callus cells and to produce resistant tomato plants, the biological activities of a crude toxin against tomato plants and callus cells were compared with the pathogenic effects of the bacterium. In callus cells co-cultured with the bacterium, susceptible cultivars had a higher percentage of dead cells than resistant cultivars, which showed apparent differences in resistance. Similar responses were obtained with callus cells treated with a crude toxin precipitated with 30 to $40 \%$ saturation of ammonium sulfate. These results paralleled closely inoculation tests to whole plants. In tomato cuttings treated with unheated and heated $\left(120^{\circ} \mathrm{C}, 5 \mathrm{~min}\right)$ toxin transpiration rates decreased to 20 to $30 \%$ and wilting symptoms occurred both in the resistant and the susceptible cultivars, although the activity of heated toxin was attenuated. This result suggests that heat-labile component(s), such as protein(s), may be associated in the toxin activity, in addition to the heat-stable components, such as polysaccharides.
\end{abstract}

(Received April 26, 1993)

Key words: Clavibacter michiganensis subsp. michiganensis, tomato plant, bacterial canker, biological activity of toxin, selection of toxin-tolerant callus cell.

\section{INTRODUCTION}

Bacterial canker of tomato, caused by Clavibacter michiganensis subsp. michiganensis (formerly Corynebacterium michiganense pv. michiganense), occurs throughout the world's tomato cultivating regions. The disease shows two typical symptoms; one is canker or necrotic lesions on leaves, stems and fruit, and the other is wilting of leaves and shoots.

Rai and Strobel ${ }^{2,3)}$ found that the pathogenic bacterium produces a phytotoxic high molecular weight glycopeptide which consists of sugars and a minor protein moiety, and causes wilting on tomato cuttings. Wilting has been considered to be due to changes in cell plasma membranes in leaves rather than to mechanical plugging of xylem vessels. The toxin also inhibited tomato callus cells in suspension culture $^{1)}$. Recently, Van den Bulk et al. ${ }^{8)}$ characterized the components of an extracellular polysaccharide (EPS) produced by this bacterium, consisting of three sugars and three organic acids, but no protein moiety. It is still unclear, whether pathogenicity is due to the sugars only or whether other factors are involved.

Our final goal is to select toxin-tolerant callus cells and determine whether the regenerated tomato plants are resistant to bacterial canker disease. For this purpose we first examined the biological effects of the toxin on tomato plants and suspension-cultured callus cells.

* Faculty of Agriculture, Tokyo University of Agriculture and Technology, Fuchu, Tokyo 183, Japan 東京農 工大学農学部 


\section{MATERIALS AND METHODS}

Bacterial isolates and culture conditions. Six isolates of Clavibacter michiganensis subsp. michiganensis, NIAES 1043 and 1044 from National Institute of Agro-Environmental Sciences, Y.M. 8611 and Tc-28 from National Research Institute of Vegetables, Ornamental Plants and Tea, Morioka Branch, and C.m. and C.m. 1 preserved in our laboratory, were used. Each isolate was grown at $28^{\circ} \mathrm{C}$ for 2 days on Potato ring-rot agar medium (decoction of potato $300 \mathrm{~g} /$ liter, $\mathrm{NaNO}_{3} 1 \mathrm{~g}, \mathrm{NaCl} 2 \mathrm{~g}, \mathrm{Na}_{2} \mathrm{HPO}_{4}$ $2 \mathrm{~g}$, peptone $10 \mathrm{~g}$, sucrose $20 \mathrm{~g}$ and agar $20 \mathrm{~g}, \mathrm{pH}$ 7.0) before use in inoculation or toxin production.

Tomato plants. Six cultivars of tomato, Lycopersicon esculentum Mill, were used. Cultivars Ohgata Zuiko, Zuiko 102, Sekai-ichi and Fukuju 2 have been considered as susceptible, and Zuiko 208 and S-319 as resistant. Tomato seeds were sowed in autoclaved soil in clay pots of $15 \mathrm{~cm}$ diameter. After 2 weeks of sowing the seedlings were transplanted to other pots containing $20 \mathrm{~g} /$ pot of $10-25-10$ (N-P-K) fertilizer and grown in the greenhouse at $22-30^{\circ} \mathrm{C}$.

Preparation of tomato callus cells. Callus cells were induced at $28^{\circ} \mathrm{C}$ in dark from stem pieces of tomato plant cultivated under aseptic conditions. The induction medium used was Murashige and Skoog (MS) agar medium with $4 \mathrm{mg} / 1 \mathrm{NAA}$ and $0.1 \mathrm{mg} / 1 \mathrm{BA}$. Induced callus cells were transferred to MS agar medium containing $0.2 \mathrm{mg} / 12,4-\mathrm{D}$ and $0.1 \mathrm{mg} / 1 \mathrm{BA}$, according to the method described by Toyoda et al. ${ }^{5)}$ Callus cell suspension was cultivated at $28^{\circ} \mathrm{C}$ in dark in Erlenmeyer flask containing 40 $\mathrm{ml}$ of MS liquid medium with $0.2 \mathrm{mg} / 12,4-\mathrm{D}$ and $0.1 \mathrm{mg} / 1 \mathrm{BA}$ with shaking at $70 \mathrm{rpm}$.

Toxin extraction. Bacterial cells grown on Potato ring-rot agar medium at $28^{\circ} \mathrm{C}$ for 2 days were transferred to $250 \mathrm{ml}$ of YDC medium described by Spencer and Gorin ${ }^{4}$ ) (glucose $15 \mathrm{~g}, \mathrm{CaCO}_{3} 5 \mathrm{~g}$ and yeast extract dialysate $10 \mathrm{~g} /$ liter of distilled water, $\mathrm{pH}$ 6.5) and incubated at $25^{\circ} \mathrm{C}$ for 5 days with shaking at $100 \mathrm{rpm}$. The culture suspension was centrifuged at $10,000 \times g$ for $30 \mathrm{~min}$, and the supernatant was collected. The toxin was precipitated overnight at $5{ }^{\circ} \mathrm{C}$ with $30-40 \%$ saturation of ammonium sulfate, and obtained by centrifugation at $10,000 \times \mathrm{g}$ for $10 \mathrm{~min}$. The precipitated toxin was dissolved in distilled water, and then dialyzed against distilled water 4 times followed by freeze-drying. The freeze-dried preparation was used as a crude toxin.

Inoculation assay to plant and callus cell of tomato. A hypocotyl part of tomato about one month old was inoculated with $c a .10^{8} \mathrm{cfu} / \mathrm{ml}$ of bacterial suspension by a needle-prick inoculation method with a bundle of six needles. About one month after inoculation, the wilting level of each leaf was observed and the disease index was calculated by the following formula. Disease index $=(4 \times A+$ $3 \times B+2 \times C+1 \times D+0 \times E$ )/number of plants per pot; criterion $0=$ no wilting, $1=1-20 \%$ of leaves on a plant wilted, $2=21-50 \%$ of leaves wilted, $3=51-80 \%$ of leaves wilted and $4=81-100 \%$ of leaves wilted; $A, B, C, D$ and $E$ are the number of plants showed the respective criterion.

Five $\mathrm{ml}$ of callus cell suspension $\left(c a .10^{6}\right.$ cells $/ \mathrm{ml}$ ) cultured for 14 days was transferred to $40 \mathrm{ml}$ of MS liquid medium, inoculated with the bacterial suspension at a final concentration of $c a .10^{4} \mathrm{cfu} / \mathrm{ml}$ and incubated at $28^{\circ} \mathrm{C}$ in dark with shaking at $70 \mathrm{rpm}$. The percentage of dead callus cells was calculated using a phenol-safranine stain method.

Bioassay of toxin activity to tomato cuttings and callus cells. Hypocotyl portions of tomato seedlings at 2-3 weeks were cut off for testing. In a measurement of transpiration of cutting ${ }^{6}$, a cutting was inserted in a vial containing $20 \mathrm{ml}$ of distilled water, and weighed. After $2 \mathrm{hr}$ of incubation at $21^{\circ} \mathrm{C}$ under an illumination of room fluorescent lamps, the vial was re-weighed, and the decrease in weight was considered as the amount of transpiration of the cutting (control). Then, the same cutting was transferred to another vial containing $20 \mathrm{ml}$ of toxin solution (at a concentration of $c a .100 \mu \mathrm{g} / \mathrm{ml}$ ) and weighed. After $2 \mathrm{hr}$ of incubation in the same conditions, the decrease in weight was measured and considered as the amount of transpiration (treatment). Toxin activity was determined by the ratio of transpiration rates calculated from the following formula; transpiration rate $=($ transpiration of the cutting in toxin solution) $\times 100 /$ (transpiration of the same cutting in water). The toxin with heat treatment at $120^{\circ} \mathrm{C}$ for 5 min was also assayed.

Toxin activity against tomato callus cells was measured by almost the same method as described 
above using bacteria-callus cells co-suspension cultures. For addition with toxin into the callus cell suspension culture, the toxin was sterilized by autoclaving $\left(120^{\circ} \mathrm{C}, 5 \mathrm{~min}\right)$ because it was difficult to sterilize by filtrating due to high molecular weight and viscosity of the toxin. Heated toxin $\left(120^{\circ} \mathrm{C}, 5 \mathrm{~min}\right)$ was added into callus cell suspension culture at the final concentration of $5 \mathrm{mg} / \mathrm{ml}$, and the percentage of dead callus cells was determined as described above.

\section{RESULTS}

\section{Evaluation of resistance in tomato cultivars and virulence of bacterial isolates in inocula- tion tests}

In the inoculation tests with the isolate NIAES 1044, Ohgata Zuiko and Zuiko 102 were susceptible, with disease indexes (over 3.3) statistically significantly higher than Zuiko 208 and S-319 (1.1 to 2.4) (Table 1).

In inoculation tests with the six isolates to the two tomato-cultivars, susceptible Zuiko 102 and resistant Zuiko 208, only the isolate C.m. showed a low disease index, and the other five isolates indicated high virulence with no significant differences in their disease indexes (Table 2).

Evaluation of resistance in tomato cultivars and virulence of bacterial isolates in callus cell-bacterium co-cultures

Callus cells from the six cultivars were co-cultured with the isolate NIAES 1044 in suspension culture (Fig. 1). The percentage of dead callus cells in suspension culture without the bacteria was less

Table 1. Measurement of degree of resistance in four tomato cultivars by a needle-prick inoculation with Clavibacter michiganensis subsp. michiganensis NIAES 1044 isolate

\begin{tabular}{lccc}
\hline \hline \multirow{2}{*}{ Cultivars } & \multicolumn{3}{c}{ Average of disease index } \\
\cline { 2 - 4 } & Experiment I ${ }^{\text {a) }}$ & Experiment II & Experiment III \\
\hline Ohgata Zuiko & $3.3 \mathrm{~b}^{\mathrm{b}}$ & $3.3 \mathrm{~b}$ & $4.0 \mathrm{c}$ \\
Zuiko 102 & $3.7 \mathrm{c}$ & $3.4 \mathrm{~b}$ & $3.7 \mathrm{c}$ \\
Zuiko 208 & $2.0 \mathrm{a}$ & $1.1 \mathrm{a}$ & $2.4 \mathrm{~b}$ \\
S-319 & $1.7 \mathrm{a}$ & $1.3 \mathrm{a}$ & $1.1 \mathrm{a}$ \\
\hline
\end{tabular}

a) The value in each experiment is an average of 4 pots ( 1 pot with 5-6 plants).

b) In each column, the values followed by the same letter are not significantly different at $p=0.05$ according to Student's $t$-test.

Table 2. Measurement of degree of virulence in six isolates of Clavibacter michiganensis subsp. michiganensis by a needle-prick inoculation to tomato plants

\begin{tabular}{cllc}
\hline \hline \multirow{2}{*}{ Cultivars } & Bacterial isolates & \multicolumn{2}{c}{ Average of disease index } \\
\cline { 3 - 3 } & & $15^{\mathrm{a})}$ & 30 \\
\hline & NIAES 1044 & $1.5 \mathrm{~d}$ b) & $3.5 \mathrm{~d}$ \\
Zuiko & NIAES 1043 & $1.4 \mathrm{~d}$ & $3.8 \mathrm{~d} c$ \\
102 & C.m. & $0.5 \mathrm{bc}$ & $3.9 \mathrm{~d}$ \\
(susceptible) & Tc-28 & $1.8 \mathrm{ef}$ & $3.5 \mathrm{~d}$ \\
& YM 8611 & $1.6 \mathrm{de}$ & $3.9 \mathrm{~d}$ \\
\hline & C.m. 1 & $2.0 \mathrm{f}$ & $1.6 \mathrm{bc}$ \\
Zuiko & NIAES 1044 & $0.3 \mathrm{ab}$ & $2.1 \mathrm{c}$ \\
208 & NIAES 1043 & $0.5 \mathrm{bc}$ & $0.2 \mathrm{a}$ \\
(resistant) & C.m. & $0.1 \mathrm{a}$ & $1.9 \mathrm{c}$ \\
& Tc-28 & $0.6 \mathrm{bc}$ & $1.8 \mathrm{bc}$ \\
& YM 8611 & $0.7 \mathrm{bc}$ & $1.3 \mathrm{~b}$ \\
\hline
\end{tabular}

a) Days after inoculation.

b) In each column, the values followed by the same letter are not significantly different at $p=0.05$ according to Student's $t$-test. Each value is the average of disease index of 3 pots ( 1 pot with 6 plants). 


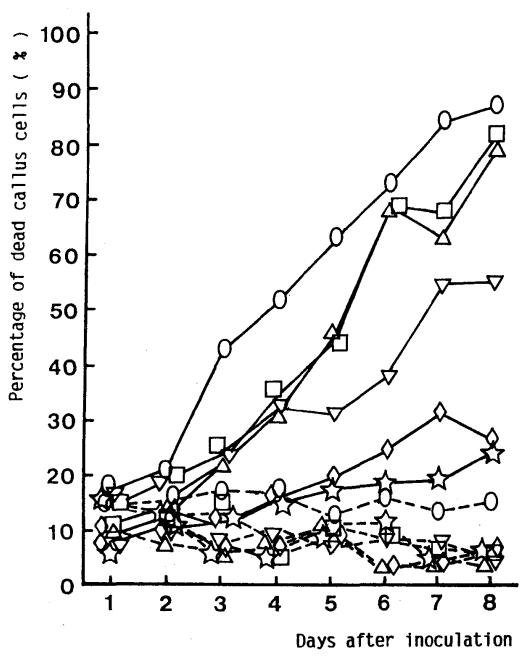

Fig. 1. Percentage of dead tomato callus cells of 6 cultivars in co-suspension culture with Clavibacter michiganensis subsp. michiganensis NIAES 1044 isolate. Callus cells in culture suspension without $(---)$ or with $(\longrightarrow)$ the bacteria. Cultivars: Zuiko $102(0)$, Ohgata Zuiko ( $\square$ ), Fukuju $2(\triangle)$, Sekai-ichi $(\nabla)$, Zuiko $208(\diamond)$, S-319 (灾).

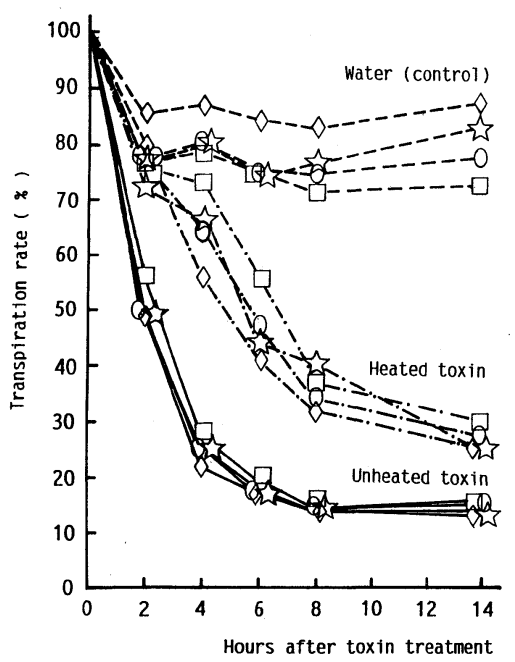

Fig. 2. Decrease in transpiration rate in cuttings of 4 tomato cultivars by the treatment of heated $\left(120^{\circ} \mathrm{C}, 5\right.$ $\mathrm{min})$ and unheated toxin obtained from Clavibacter michiganensis subsp. michiganensis NIAES 1044 isolate. Cultivars: Zuiko $208(\diamond)$, S-319 ( $)$, Zuiko $102(0)$, Ohgata Zuiko ( $\square)$. Treatment with water (control) (---), heated toxin $(-\bullet-)$ or unheated toxin $(-)$.

than $20 \%$ in all cultivars. In co-culture with bacteria, the percentages of dead callus cells in susceptible cultivars, such as Zuiko 102, Ohgata Zuiko and Fukuju 2, were so high at $80-90 \%$, but in another susceptible Sekai-ichi it was near to $60 \%$. The susceptibility of both cultivars of Fukuju 2 and Sekai-ichi was confirmed by another inoculation test to tomato plants (data not shown). On the other hand, the percentages in resistant cultivars, such as Zuiko 208 and S-319, were $20-30 \%$. These results show that the percentages of dead callus cells were almost parallel to the degree of resistance in the inoculation tests.

In co-cultures with six bacterial isolates in combination with susceptible Ohgata Zuiko and resistant 


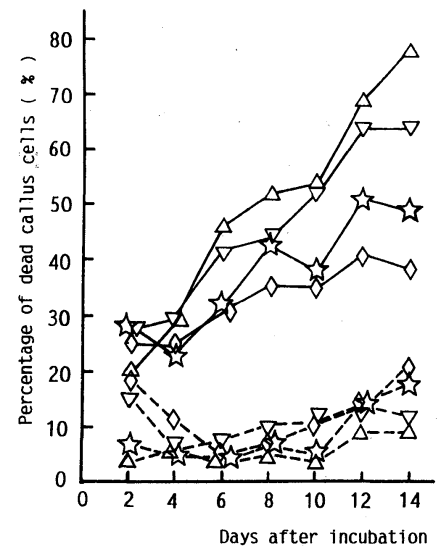

Fig. 3. Effect of heat-treated toxin obtained from Clavibacter michiganensis subsp. michiganensis NIAES 1044 isolate on survival of callus cells derived from 4 tomato cultivars in suspension culture. Callus cells in culture suspension without $(--)$ or with $(-)$ the toxin. Cultivars: Fukuju $2(\triangle)$, Sekai-ichi $(\nabla)$, S-319 (纤), Zuiko $208(\diamond)$.

Zuiko 208, isolates showed no significant differences in the percentage of dead callus cells (data not shown).

\section{Effect of the toxin on transpiration and wilting of tomato cuttings}

In this test susceptible cultivars Ohgata Zuiko and Zuiko 102 and resistant ones Zuiko 208 and S-319 were used. The toxin was prepared from the isolate NIAES 1044 and the activity was evaluated by the decrease in transpiration rate and occurrence of wilting of tomato cuttings at $14 \mathrm{hr}$ after toxin treatment.

Transpiration rate in tomato cuttings of all cultivars without treatment with the toxin (control) was high, $70-85 \%$ (Fig. 2). In treatment with the unheated toxin, transpiration rates decreased rapidly to $20-$ $30 \%$ and wilting symptoms occurred $4 \mathrm{hr}$ after the treatment, with no differences among the cultivars. In treatment with the heated toxin $\left(120^{\circ} \mathrm{C}, 5 \mathrm{~min}\right)$, however, the response of cuttings was delayed somewhat. Four hr after treatment, all cultivars maintained transpiration at 55 to $75 \%$, and no wilting symptoms occurred. However, $8 \mathrm{hr}$ after treatment, transpiration rates decreased to $30-40 \%$ and wilting symptoms became visible. It is noticeable that no differences among the cultivars in any treatment with the toxin were observed in transpiration rate and occurrence of wilting, and that the activity of the heated toxin was attenuated in comparison with that of the unheated toxin.

The toxins from the five isolates (NIAES 1043, 1044, Tc-28, Y.M. 8611, C.m.) had similar effects on transpiration rate and occurrence of wilting in Zuiko 208 (data not shown).

\section{Effect of the toxin on survival of tomato callus cells}

The heated toxin from the isolate NIAES 1044 was added to callus cells in suspension cultures of susceptible cultivars Sekai-ichi and Fukuju 2 and resistant ones Zuiko 208 and S-319 at final concentration of $5 \mathrm{mg} / \mathrm{ml}$. Fourteen days after incubation, the dead cells were measured (Fig. 3).

In control, the percentages of dead cells in all cultivars were less than $20 \%$. In treatment with the heated toxin, susceptible Fukuju 2 and Sekai-ichi showed high percentages of dead cells, about $80 \%$ and $65 \%$, respectively. In contrast, resistant Zuiko 208 and S-319 showed lower percentages, less than $40 \%$ and $50 \%$, respectively.

These results indicated that the callus cells derived from the resistant cultivars were more tolerant to the toxin than those from the susceptible ones. In other words, this interaction between callus cells and toxin may reflect the interaction between tomato plant and the pathogenic bacterium. 


\section{DISCUSSION}

In callus cells co-cultured with bacteria, the cells derived from the susceptible cultivars had many dead cells, but those from the resistant cultivars only few, with apparent differences. Similar responses were obtained also in callus cells treated with the toxin. These results paralleled closely those of inoculation tests to whole plants, indicating the feasibility for selection and/or evaluation system of resistant tomato cultivars to bacterial canker disease, in addition to field tests. However, some exceptions not correlated with inoculation tests to whole plants may appear in treatment with the toxin, as reported by Van den Bulk et al. ${ }^{7)}$

In this study we have used the crude toxin precipitated with ammonium sulfate, because it remains unclear whether the toxin activity is due to only sugars, or whether some other factors are also involved in the pathogenicity. The heated and the unheated toxin affected transpiration rate and wilting of cuttings in both resistant and susceptible cultivars, although the activity of the heated toxin was attenuated. We do not know why the toxin had the same effect in both resistant and susceptible cultivars. However, our results suggest that transpiration rate and wilting tests are good for evaluation of toxin activity, but not for selection of resistant cultivars. Also, some heat-labile component(s), such as protein(s), may be associated with the toxin activity, in addition to heat-stable component(s), such as polysaccharides. Wallis ${ }^{9)}$ suggested that lytic enzymes may be involved in occurrence of wiltings by this bacterium, based on ultrastructural observations. Isolation and characterization of the heat-labile substance(s) may elucidate the role of the toxin in pathogenicity, as well as help in producing new resistant cultivars.

The authors are grateful to National Institute of Agro-Environmental Sciences and National Research Institute of Vegetables, Ornamental Plants and Tea, Morioka Branch for kindly providing the isolates of the pathogenic bacterium. We are also grateful to Sakata Seed Corp. for kindly giving the tomato seeds.

\section{Literature cited}

1. Krämer, R., Schlegel, H. und Opel, M. (1988). Reaktion von Zellsuspensionskulturen der Tomate auf das Toxin von Clavibacter michiganensis subsp. michiganensis (Smith) Davis u.a. [Syn.: Corynebacterium michiganense pv. michiganense (Smith) Jensen]. Arch. Phytopath. Pflanzenschutz 24 : 325-334.

2. Rai, P.V. and Strobel, G.A. (1969). Phytotoxic glycopeptides produced by Corynebacterium michiganense. I. Methods of preparation, physical and chemical characterization. Phytopathology 59:47-52.

3. Rai, P.V. and Strobel, G.A. (1969). Phytotoxic glycopeptides produced by Corynebacterium michiganense. II. Biological properties. Phytopathology $59: 53-57$.

4. Spencer, J.F.T. and Gorin, P.A.J. (1961). The occurrence in the host plant of physiologically active gums produced by Corynebacterium insidiosum and Corynebacterium sepedonicum. Can. J. Microbiol. 7: 185-188.

5. Toyoda, H., Tanaka, N. and Hirai, T. (1984). Effects of the culture filtrate of Fusarium oxysporum f. sp. lycopersici on tomato callus growth and the selection of resistant callus cells to the filtrate. Ann. Phytopath. Soc. Japan $50: 53-62$.

6. Van Alfen, N.K., McMillan, B.D. and Wang, Y. (1987). Properties of the extracellular polysaccharides of Clavibacter michiganense subsp. insidiosum that may affect pathogenesis. Phytopathology 77 : 501-505.

7. Van den Bulk, R.W., Löffler, H.J.M. and Dons, J.J.M. (1990). Inhibition of callus development from protoplasts of Lycopersicon peruvianum by extracellular polysaccharides of Clavibacter michiganensis subsp. michiganensis. Plant Science $71: 105-112$.

8. Van den Bulk, R.W., Zevenhuizen, L.P.T.M., Cordewener, J.H.G. and Dons, J.J.M. (1991). Characterization of the extracellular polysaccharide produced by Clavibacter michiganensis subsp. michiganensis. Phytopathology $81: 619-623$.

9. Wallis, F.M. (1977). Ultrastructural histopathology of tomato plants infected with Corynebacterium michiganense. Physiol. Plant Pathol. 11 : 333-342. 


\section{和 文 摘 要}

上野ベルナルド・寺岡 徹・細川大二郎・渡辺 實：トマトかいよう病細菌毒素のトマト植物・カルス細胞に対する 生物活性

トマトかいよう病細菌 Clavibacter michiganensis subsp. michiganensis の萎ちょう毒素に耐性のトマトカルス細胞 を選抜し, かいよう病抵抗性個体を作出することを目的とし, まず, トマト植物体及びカルス培責細胞に対する病原細 菌の病原性と毒素の生物活性を比較検討した。カルス培養細胞と細菌との混合培養において, 感受性品種由来のカルス 細胞の死滅率が抵抗性品種由来のカルス細胞より明らかに高かった。また, 病原細菌培養ろ液から $30 \sim 40 \%$ 飽和硫安塩 析で抽出した粗毒素をカルス懸濁培養に添加した場合も同様な反応が認められた。これらの結果は, 接種試験で植物体 が示した各品種の抵抗性程度とほぼ同様であった。熱無処理と熱処理(120 $\mathrm{C}, 5$ 分間)した粗毒素をトマト切り苗に吸収 させた結果，抵抗性，感受性品種とも同様に苗の蒸散率を 20～30\%に減少させて，萎ちょう症状を誘起したが，熱処 理毒素の活性は若干低かった。この結果から, 本毒素活性に多糖質のような耐熱性成分に加えてタンパク質のような熱 不安定な成分が関与する可能性が示唆される。 